\title{
EMPEROR HADRIAN AND EGYPT. REMARKS ON THE MYTHICAL AND RELIGIOUS PERSPECTIVES \\ El EMPERAdor Adriano y EgIPTO. OBSERVACIONES SOBRE LAS PERSPECTIVAS MÍTICAS Y RELIGIOSAS
}

\author{
Giuseppina Capriotti VitTozzi \\ italian Archaeological Centre, Cairo \\ GIUSEPPINA.CAPRIOTTI@ESTERI.IT
}

\section{ABSTRACT}

The aim of these remarks is to bring to light some particular aspects in the enigmatic religious, mythological and ideological system inspired by Egypt, built into the Hadrianic environment, and the intercultural commitment, to which specialists of heterogeneous origin, and therefore also Egyptians, probably contributed. The phoenix is taken into account as image of the renovation of kingship, as well as other figures expressing the regenerating transfer of royalty in an Egyptian cyclic perspective.

\section{RESUMEN}

El objetivo de estas anotaciones es traer a la luz algunos aspectos particulares del sistema religioso, enigmático, mitológico e ideológico inspirado por Egipto, construido en el entorno adrianeo, y la relación intercultural, en la que probablemente contribuyeron especialistas de origen hetereogéneo y por lo tanto también egipcios. El fenix es tenido en cuenta como imagen de renovación de la realeza, así como otras figuras que expresan la transferencia regenerativa de la realeza en una perspectiva cíclica Egipcia. 
KEYWORDS

Emperor Hadrian, Egypt, Egyptian religion, phoenix, Apis bull
PALABRAS CLAVE

Emperador Adriano, Egipto, religión egipcia, fénix, toro Apis 


\section{INTRODUCTION}

Much has been written about the Emperor Hadrian and his relationship with Egypt, in particular through the figure of Antinous. I return to this subject, on the occasion of the project "Adriano y la integración de la diversidad regional: una perspectiva histórica e historiográfica", with some comments arising from the documentation and bibliography collected over recent years. This study is an attempt to trace the path of the vision that Hadrian had of Egypt, with a particular regard to his commitment to interpreting the ancient mythological vision of the land of the Pharaohs and to revive it in his own era, creating new myths and liturgies.

Since my first approach to this topic, ${ }^{1}$ I was struck by the cultured interweaving that reveals the collaboration of Egyptian specialists, ${ }^{2}$ and Hadrian's commitment to rekindle ancient traditions, refueling them with new life, stimulating new creativity, enhancing the various "souls" of the Empire, giving rise to a phenomenon that, albeit more limited, recalls in some respects the fertility of Hellenism: a new impulse through which Egypt came to contribute to the Mediterranean koinè, expressing itself - in this case - mainly in an élite environment.

The vision that the Emperor had of the East and his travels have been repeatedly analysed and commented on, with particular reference to the Greek world and to Egypt. ${ }^{3}$ In this regard, it is worth mentioning a recent study by J. López Benítez on the presence of Hadrian at Delphi and on the interpretation of this presence in accordance with attributes typical of the Hellenistic tradition concerning divinity. The

1. Capriotti Vittozzi, 2009.

2. For an analysis of this subject: Capriotti Vittozzi, 2013a, pp. 85-87 with previous bibliography. More recently Capponi, 2017, pp. 119-122.

3. See for example Calandra, 2010 with previous bibliography; Birley, 2013. 
Emperor, in fact, introduced himself into the space and the religious calendar of a city which took its character from the presence of an important oracle. ${ }^{4}$

While much has been written about the journey of Hadrian to Egypt in 130, during which Antinous drowned in the Nile, it is interesting to quote another hypothesis, elaborated over recent years by L. Capponi, ${ }^{5}$ on the possibility that the Emperor had travelled to Egypt as early as 117, immediately after his accession to power. The collection of documents, from papyri to literary sources, creates an enthralling framework, even if it isn't a definitive proof. However, we should still take into consideration the possibility that some initiatives introduced by Hadrian in Egypt could be attributed to the beginning of his reign and not to his journey in 130 .

Nevertheless, whatever happened, Hadrian's interest for Egypt clearly arises at the beginning through a remarkable item: the aureus representing a phoenix, ${ }^{6}$ minted at the beginning of Hadrian's era. A choice that is so specific and highly innovative, is certainly significant.

Amongst subsequent relations between Hadrian and Egypt, the journey of 130 is undoubtedly the period most full of meaning and consequence, with the death of Antinous, the recognition of the young as a deity, the foundation of Antinoupolis, the realization of particular buildings and furnishings for Villa Adriana, ${ }^{7}$ for Antinoupolis $^{8}$ and, perhaps, for other spaces in Rome. ${ }^{9}$ In regard to this subject, there is a wide bibliography. ${ }^{10}$

The aim of these remarks is to bring to light some particular aspects in the religious and mythological sphere, on the background of a well-known and widely commented on framework.

\footnotetext{
4. López Benítez, 2015.

5. Capponi, 2010a.

6. van Den Broek, 1972, p. 245. A sample in the British Museum: https://www.bmimages.com/preview. asp? image $=00535894001$ \&itemw $=4 \&$ itemf $=0002$ \&itemstep $=41$ \&itemx $=62$. About the subject: infra .

7. Frischer et al., 2016, with previous bibliography.

8. Grimm, Kessler and Meyer, 1994, pp. 91-136; http://antinoupolis.net/blog/2017/2/17/the-possible-osiristemple; http://antinoupolis.net/blog/2017/2/27/the-temple-briefly; http://antinoupolis.net/blog/2017/10/20/ new-excavation-season-underway-at-antinoupolis; $\quad$ http://antinoupolis.net/blog/2017/2/28/blockbusternews

9. Grenier, 2008, pp. 37-46, with previous bibliography.

10. We mention here only the most recent bibliography, from which it is possible to derive the previous one.
} 


\section{The PHOENIX ON The Hadrian COINAge}

During Hadrian's reign, his coins show the specific interest that the Emperor had in the phoenix. ${ }^{11}$ The phoenix, well known from classical sources, ${ }^{12}$ in particular through Herodotus, ${ }^{13}$ represents continuity and renewal, in its link with the Heliopolitan cult. The mention of the phoenix in Roman sources dating back to the period that came just before the Hadrian empire, is found in Pliny ${ }^{14}$ and Tacitus. ${ }^{15}$ Herodotus narrates the journey from the East undertaken by the mythical bird, a journey aimed at regeneration, and which follows the solar transit, highlighting the cyclical Egyptian vision of the renewal of life. The phoenix transmitted by the classical authors can be traced back to the benu bird ( $b n w$ ) of the Pharaonic tradition. ${ }^{16}$ Closely linked to the moment of creation, the mythical bird is connected with Ra and Osiris, in its path to solar and cosmic regeneration. As a manifestation of the solar divinity, its name shares its root with webn "rise, shine, appear" ${ }^{17}$ and with benben,${ }^{18}$ the upraised stone, hypostasis of the solar deity. ${ }^{19}$ The phoenix watches over the tomb of Osiris ${ }^{20}$ and is connected to the Sed-festival, the jubilee for the renewal of royalty. ${ }^{21}$ By expressing the solar cycle, from death to resurrection, in the link between Ra and Osiris, the phoenix can express the renewal of royalty.

Right after Hadrian's rise to power, came the aureus bearing on one side the profile of his predecessor and on the other the phoenix whose head is wrapped in the nimbus. It is an image that recalls the one depicted on a liturgical robe from Saqqara. ${ }^{22}$

According to the scholar G. Camuzzi, ${ }^{23}$ the aureus was destined to celebrate the consecratio of Trajan and it should be dated to the earliest period of Hadrian's rise to power, as early as August 117 . The following critical studies also proposed dating it to

11. Martin, 1974.

12. See van de Broeck, 1972; Harris, 1978; Tammisto, 1986 and, more recently, Lecocq, 2008a and Nigg, 2016.

13. Hdt., II 73, 1-4. Cf. Asheri, Lloyd and Corcella, 2007, pp. 287-288.

14. Plin., HN X 2.

15. Tac., Ann. VI 28. We can notice the chronological proximity of Tacitus to the Hadrianic aureus.

16. Kákosy, 1982; van den Broek, 1972; El Banna, 1989; Ciampini, 1999; Quirke, 2001; Nigg, 2016.

17. $W b 1,292.9-294.3$.

18. $W b 1,459.5-11$.

19. See also Stephens, 2003 and Capriotti Vittozzi, 2005.

20. Étienne-Fart, 1994, p. 138.

21. van den Broek, 1972, pp. 22-23; Tolmatcheva, 2003.

22. Perdrizet, 1934.

23. Camuzzi, 1901a. See also Mattingly, 1936, pp. CXXVII e 245, e Lecocq, 2001. 
$118,{ }^{24}$ therefore offering food for thought about the different meanings of the phoenix..$^{25} \mathrm{M}$. Christol emphasized the presence of the phoenix more as an indication of the passing of power from Trajan to Hadrian, than as a reference to the consecratio of the former, ${ }^{26}$ Camuzzi himself had underlined the absolute novelty of Hadrian's coins depicting the phoenix and how they evoked the capacity for perennial renewal. ${ }^{27}$ The particular value of the phoenix on this coin, where the phoenix is placed in close proximity to Trajan, has also been recognized by other scholars as an expression of the commitment of the new Emperor to bury, like the phoenix, his father, and to make him live again through his own reign: ${ }^{28}$ a promise of the regeneration of fruitful power and, at the same time, its legitimization. Moreover, we can consider that Hadrian inherited a problematic situation because of the Jewish revolt, ${ }^{29}$ therefore the phoenix can be also the symbol of the start of a new era of stability.

In some specimens, the phoenix stands on a vegetal element, widely identified as a laurel branch, although some scholars see it as a palm leaf. ${ }^{30}$ The hypothesis of the palm is certainly fascinating, as it connects the mythical bird to the tree, that reflects a topic in Egyptian culture ${ }^{31}$ and the phonetic structure of its Greek name, but we must admit that in no way does the vegetal element depicted resemble a palm leaf.

The choice of the phoenix, represented on the coins dedicated to the memory of Trajan, is in itself very eloquent, both for the obvious meaning related to the succession of power, and for the early interest shown by Hadrian in Egyptian traditions.

A second Hadrianic coin shows the image of the phoenix, ${ }^{32}$ in this case depicted on a smaller scale, in the hands of a variously identified virile figure enclosed in the oval of the zodiac. The legenda mentions the Saeculum aureum. This type of coin, that has been widely discussed, would have been minted in $121,{ }^{33}$ the year in which

24. See for example (with the previous bibliography) van den Broek, 1972, p. 245; Lecocq, 2009; Diegi, 2013; Nigg, 2016, p. 61.

25. See for example Martin, 1974. For a discussion about this subject see Lecocq, 2009, p. 86.

26. Christol, 1976, p. 83, with previous bibliography.

27. Camuzzi, 1901b, p. 51.

28. Gury, 1984, p. 21, with previous bibliography.

29. Capponi, 2017.

30. Lecocq, 2009, p. 85.

31. For the meaning of the palm in Ancient Egypt: Wallert, 1962.

32. Mattingly, 1936, p. 278. A remarkable sample is kept at Münzkabinett, Staatliche Museen zu Berlin: http://isaw.nyu.edu/exhibitions/time-cosmos/objects/aureus-zodiac-phoenix.

33. Gury, 1984; Quet, 2004; Lecocq, 2009, pp. 86-87. 
Hadrian inaugurated a series of celebrations, among which the Natalis Romae, aimed at emphasizing the Renovatio temporum. ${ }^{34}$

This coin, of notable figurative value, responds to a complex cultural elaboration, from which a multifaceted image has emerged, whose expressive subtlety has been well analyzed by F. Gury and M.-H. Quet. F. Gury ${ }^{35}$ commented on the image by retracing certain philosophical reflections that depict time as a hoop that is left spinning, up to the vision of the Stoic Dion Chrysostom, for whom the universe is similar to a circle. ${ }^{36}$ In the representation of the zodiac on the coin, an interesting choice was made: a rigid circle shown in a three-quarter view, so as to expose, on the external part - visible at the left side when we face the coin - the sign of Gemini, ${ }^{37}$ from which it is possible to reconstruct the position of the other signs. F. Gury and M.-H. Quet have pointed out certain aspects of this image: the human figure inside the zodiac rests his right hand in correspondence with the sign of Aries, considered the princeps signorum and linked to the spring equinox. ${ }^{38}$ Aries was the first of the zodiac signs and the start of the renewal process. The position of the protagonist's hand in the scene is rather interesting and determines further observations: not only does it indicate Aries, but it also rests its fingers on the rigid circle of the zodiac, passing its arm, whose muscle tenses, behind the circle itself. Therefore we get the precise impression that the hand is giving a push to the wheel, in order to make it turn; this impression can however be diminished or contradicted by the position of the left foot that seems to rest on the circle, or is, perhaps, passing through it. Whether this character is a juvenile Aion, to be interpreted as a vital force and a source of vitality, ${ }^{39}$ as F. Gury believes, or whether it represents the Saeculum aureum initiated by Hadrian in the spring of 121, as proposed by M.-H. Quet, the strong allusion to cyclic renewal and the active function of the human figure is evident. ${ }^{40}$ On the other hand, the position of the phoenix is equally interesting: the central figure, in fact, interacts with the wheel of the zodiac in three symmetrical points: the hand of the human figure, which seems to be giving a push, the beak of the phoenix, pointing specifically to the zodiac in a symmetrical manner, the left foot of the human figure resting on the

34. Gury, 1984, p. 9; Quet, 2004, pp. 124-125.

35. Gury, 1984.

36. Gury, 1984, p. 20.

37. The sign is recognisable at least on some specimens: Quet, 2004, p. 128.

38. Gury, 1984, p. 18; Quet, 2004, pp. 128-131.

39. Gury, 1984, p. 10.

40. Interpreted by J. Martin as the image of Hadrian himself: Martin, 1974, later criticised, see for example Quet, 2004, p. 130. 
wheel or pasing through it. M.-H. Quet notes that the phoenix, placed on the globe, with its beak toward the zodiac, "met ainsi en relation l'orbis terrarum romain et le zodiaque" ${ }^{41}$ To this observation, we can add another: as we said, if the figure presents a specific and subtle complex of meanings, like the one attributed to the position of the hand, then the position of the beak of the phoenix should not be seen as random. We can advance the hypothesis that the phoenix indicates the birth of the Emperor, who was the new phoenix, on January 24th. The space between the hand placed before Aries and the bird's beak could well be compatible with the beginning of the zodiacal sign of Aquarius. ${ }^{42}$

As it was correctly observed by M.H. Quet, ${ }^{43}$ understanding such an image, in its refined shape and content, is a difficult task for the general public, for whom similar concepts were expressed through other kinds of coinage, along the lines of Roman tradition. The aureus with the zodiac and the phoenix could be addressed only to the cultivated entourage capable of understanding such a complex and heterogeneous code, where Greek and Roman traditions met their Egyptian and Oriental counterparts, characterized by an exotic charm and a prestigious past. It was an expression destined for a restricted and reserved group, a learned élite.

Just towards the end of the Hadrianic period, we have a new coin probably representing the phoenix: in this case it is an Alexandrian coin and the mythical bird, provided with a nimbus, is in the hand of a female figure, Pronoia in the legenda. This coin has been interpreted in relation to the adoption of Antoninus Pius by Hadrian, and therefore as a reference to the cyclic passage of royalty. ${ }^{44}$ This hypothesis was criticized by M.-H. Quet, ${ }^{45}$ who instead sees this image as an allusion to the expectation of the beginning of a new Sothic cycle, which would have taken place in $139,{ }^{46}$ just at the beginning of the empire of Antoninus Pius. It should be acknowledged that, on a coin minted in Alexandria, the hypothesis of the reference to the new Sothic cycle does seem more appropriate. ${ }^{47}$ In this regard, we should remember that the arrival of

41. Quet, 2004, p. 129.

42. For the horoscope of the Emperor, reported by Hephaestion of Thebes, see Barnes, 1976; Neugebauer and Van Noesen, 1987, pp. 80 and 90-91. I thank Paolo Sabbatini for his generous indications.

43. Quet, 2004, p. 139.

44. Martin, 1974; Lecocq, 2009, p. 87, with previous bibliography.

45. Quet, 2004.

46. O'Mara, 2003.

47. Lecocq, 2009, p. 87. 
the heron - the benu bird - would have been observed specifically in relation to the beginning of the Sothic period. ${ }^{48}$

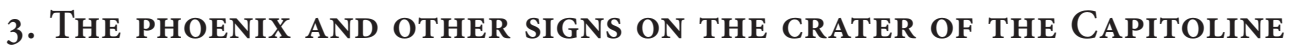 Museums}

The analysis of the presence of the phoenix on the coins of the Hadrian era pushes us back again to another Hadrianic object that probably showcases the mythical bird. It is an object full of meanings and it can still provide some data: the crater of the Capitoline Museums, which comes from Hadrian's Villa, and is characterized by complex and cryptic figurations. ${ }^{49}$

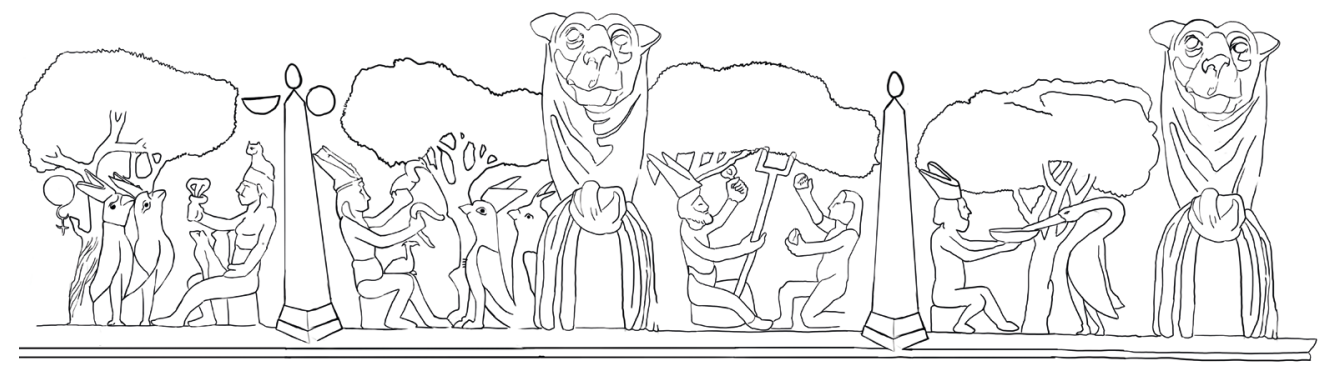

Fig. 1. Egyptianizing crater from Hadrian's Villa drawing by

Erica Bassignani. Capitoline Museums (inv. n²9).

48. van den Broek, 1972, p. 30; Franci, 2010, p. 37.

49. Rome, Capitoline Museums, inv. n²9. Ensoli Vittozzi, 1990, pp. 47-50; Capriotti Vittozzi, 2016. 
Four scenes unfold on the body of the vase: two large leonine protomes divide the surface into two symmetrical faces, each of which is divided into two scenes by an obelisk, surmounted by an oval element, which could be a scarab. ${ }^{50}$ Each of the four scenes takes place in the shade of a tree that seems to be a maritime pine, certainly not an expression of the Egyptian environment, but probably a reference to the Italian landscape ${ }^{51}$ One of the two faces presents, in its two scenes, a regal figure on a throne facing two large crowned raptors, which may be a reference to the double royalty of the Egyptian tradition. The regal seated figure is also accompanied by animal figures clinging to his lap, hands and head. ${ }^{52}$ The two scenes, albeit rather obscure, seem to have an astronomical characterization: on the sides of the top of the obelisk we find a disc and a half-disc; ${ }^{53}$ on the extreme left, another disk tied at the bottom to a cruciform element (?). While in the scene on the left the cat may refer to the goddess Bastet, maternal protector of the sovereign with a possible role in the Sed-festival, ${ }^{54}$ in the scene on the right the two figures that the sovereign is holding - a snake and a bird - suggest a reference to cyclical time and eternal regeneration. In the Egyptian imaginary the snake is a reference to time and eternity, as it is also noted in the hieroglyphic djet, generally translated as "eternity" ${ }^{55}$ Here we may recall the link between the snake and Osiris, ${ }^{56}$ well known in Roman times, and the link between the Egyptian deity, wrapped in the snake, and the Greek Aion. ${ }^{57}$ On the other hand, the bird held in the hand evokes ancient royal rituals, and this could also be read, perhaps, as a reference to the phoenix. Concerning the ancient ritual (the so-called Vogellauf) ${ }^{58}$ in which the sovereign is depicted while he runs holding a bird, we may recognize in

50. Capriotti Vittozzi, 2016.

51. In the area of the so-called Antinoeion of Hadrian's Villa traces of palms and maritime pines were found (Giardini et al., 2006; Adembri, 2012, p. 976), the latter could have a connection with Osiris: Servajean, 2011.

52. For an analysis of these elements see: Capriotti Vittozzi, 2016.

53. It is unlikely that we can read these signs as hieroglyphics in this context, as if they could lead to $n b r^{\prime}$, or supposing that a scarab crowns the top of the obelisk: $n b$ hpr $r^{\prime}$.

54. Capriotti Vittozzi, 2016.

55. See particularly Servajean, 2007.

56. Clerc and Leclant, s.v. "Osiris", in LIMC VII.1, 11, n. 7; Bresciani, 1996; Lafli, Buora and Mastrocinque, 2012; Capriotti Vittozzi, 2013b.

57. Kákosy, 1964.

58. Davis, 1943, I, 37 and II, tables. 36-37. In the tomb of Rekhmira we find the image of Thutmose III running, a typical attitude of the Sed-festival. Thutmose also offers with his hand a bird that looks like a $a k h$, the crested ibis. In Capriotti Vittozzi, 2016 this is related to the Sed-festival, since we have representations in which the sovereign runs: Bleeker, 1967, p. 119, with previous bibliography; Teissier, 1996, p. 126. 
it the akh bird, the crested ibis (Geronticus eremita). ${ }^{59}$ This is placed in relation to the deceased as he finally achieves a state of enlightenment and salvation. The $a k h u,{ }^{60}$ in Egyptian thought, were the dead that were finally taken into a state of grace: this term is sometimes translated as "the blessed souls" or even "the living (in the Afterlife)" and "the resurrected" with a capacity to mediate and interact with the world of the living. The term $a k h$ should be related to the horizon (akhet), a fundamental place in Egyptian religious thought, where heaven and earth come into contact, where the solar deity manifests itself and where the akhu live, thus participating in the solar regeneration. Taking into account the observation of nature that generally supports the assumption of animal images in the religious sphere, J. Janák, who has extensively studied the case of the crested ibis, has attempted to reconstruct the presence of this bird in Egypt, a land from which this migratory bird has long since vanished: it probably appeared there in March, with the arrival of spring, and left immediately before the flood in July, that marked the New Year; it nested on the rock cliffs of the eastern bank of the Nile and then migrated to Ethiopia and those lands of the south-east, which for the Egyptians represented an exotic and sacred environment, and which were also related to the phoenix.

The ritual in which we see the king running while holding an $a k h$ is known from rare testimonies, from the New Kingdom to the temple of Dendera, in an image dated to the first century BC. ${ }^{61}$ According to J. Janák, such images do not represent a real bird in the hand of the king, the bird must be understood as a hieroglyphic sign, with a lexical/symbolic meaning, ${ }^{62}$ a value that we can recognize in the objects held or offered by the characters depicted on the crater.

On the other half of the crater, the protagonist on the throne is a bearded figure, who may well evoke Hadrian; in the scene on the left the protagonist hands to a Pharaonic figure, similar to the one sitting on the throne in the opposite scenes and kneeling down in an attitude of offering, a long pole on which an object stands, probably the sign $\mathrm{ka}$. In the other scene, the same bearded figure holds out a bowl to a large bird that can be identified as a benu-phoenix. ${ }^{63}$

59. Janák, 2010; Janák, 2013a.

60. Janák, 2010; Janák, 2013b. Moreover: Faulkner, Ogden and Von Dassow, 2008, p. 152; Smith, 2017, pp. 44-46.

61. Janák, 2010, pp. 27-29; Janák, 2013a, p. 6.

62. Janák, 2010, p. 29.

63. This possible identification, based on the shape of the figure, on the meanings recognizable in the reliefs of the crater, and on the mythological context expressed by Egyptian and Egyptianizing items in 
Offering the $k a$ is undoubtedly a legitimation of the succession, of the passage of power, since it is a link between the sovereign and his ancestors: ${ }^{64}$ the use of this term was recognized as the translation of the Latin gens in the obelisk of Domitian in Piazza Navona. ${ }^{65}$ In the adjacent scene, the presence of the large bird, recognizable as the benu bird ${ }^{66}$ confirms the theme of the renewal of royalty through the passage from one sovereign to another. This ability of the solar bird, confirmed by the story written by Herodotus about the phoenix, qualifies the benu bird as an element belonging to far older traditions; for example, in chapter 122 of the Book of the Dead, we have one of the citations of the benu bird: "I entered as a hawk and I came out as benu". ${ }^{67}$ The range here is that of the transformations that lead the deceased to a new life: the passage from one form of bird to another is rather suggestive, considering that the falcon is the regal image par excellence. In the same chapter, the connection between the benu and the planet Venus can be detected. If the benu bird is an image of rebirth, it is not surprising that it is linked to the Sed-festival, a royal jubilee aimed at regenerating royalty. ${ }^{68}$

While reconsidering together the different images that have been analyzed, it is useful to remember an interesting study by E.M. Ciampini, that relates the ancient Egyptian tradition of the phoenix to that of the snake, two images of time. ${ }^{69}$ The phoenix represents the moment of creation and its periodic renewal; on the other hand, the snake also evokes the uroboros, the snake with its tail in its mouth, that represents a continuous circle but also suggests a rupture when it bites its tail and could let it go; this figure connects the two forms of time in the Egyptian tradition, djet and neheh, and at the same time it represents the cyclical rhythm of creation.

As it has already been pointed out, the decorative narrative of the crater, although not entirely clear, undoubtedly refers to the passage of kingship and its cyclical renewal over time: we see the explicit signs of the double kingship in ancient Egypt, such as the

the Hadrianic period, is a suggestive hypothesis that can be studied in depth.

64. Bell, 1985.

65. Ciampini, 2005, pp. 405-402; see also Grenier, 1987, p. 939.

66. We are confronted by a big wading bird with a long neck, and a long, straight beak, which is different from the beak of the ibis. We can see an affinity with the images of the Saqqara tunic and the coin with the representation of Trajan on one side (supra).

67. It is now possible to consult the Book of the Dead: Das altägyptische Totenbuch ein digitales Textzeugenarchiv; in particular this chapter: http://totenbuch.awk.nrw.de/ spruch/122\#NachweiseSpruchtext. Concerning the benu bird in the Book of the Dead, see also Faulkner, Ogden and Von Dassow, 2008, p. 159.

68. van den Broeck, 1972, pp. 22-23.

69. Ciampini, 1999. 
two crowned falcons, the possible references to the Osiriac environment and to the Sed-festival, the presence of the benu bird, of the snake, perhaps the $a k h$.

The two regal figures can be identified as Antinous - the one wearing the nemes similar to the statues depicting the young man in Pharaonic clothing - and Hadrian - the one characterized by the beard. Therefore, we have two regal figures: one concerning the regality of Antinous, clearly presented in the numerous images of him wearing Pharaonic clothing. J.-Cl. Grenier ${ }^{70}$ has dwelt on this issue noting how, in the text of the Pincian obelisk, the royal birth of Antinous is a fundamental element of his divine nature, according to Pharaonic tradition. ${ }^{71}$

The circularity of the decorated surface of the vase offers an interesting game in the succession of images of figures sitting on a throne: Antinous in Pharaonic clothing and Hadrian, in an endless cyclical sequence, and given the themes that recur in the images, the concept of circularity itself appears significant.

The connection between the regality of Hadrian and that of Antinous is not immediately comprehensible, especially in the context of the Roman environment. But it could be understood taking into account the Pharaonic elements used: royalty is passed on by Hadrian to Antinous, through the offering of the $k a$. It should be noted that the Pharaonic descent of Antinous is confirmed by the text on the obelisk. ${ }^{72} \mathrm{It}$ is possible to imagine that the regality passes from Antinous to Hadrian as though it had been vivified, through the death of the young man. ${ }^{73}$ Even the possible references to the Sed-festival would therefore make sense: the regeneration of royal power, during the Sed-festival, passed through the funerary rites ${ }^{74}$ of birth and resurrection.

E. Winter has discerned a link between Antinous and the Sedfestival in the Pincian obelisk. ${ }^{75}$ Thus, we can sense the regenerating function of the young man's death, similar to what would happen in a Sed-festival for Hadrian. ${ }^{76}$

70. Grenier, 2008, pp. 59-66.

71. Grenier, 2008, p. 60.

72. Supra.

73. Capriotti Vittozzi, 2016.

74. Uphill, 1965; Bleeker, 1967, pp. 96-123; Martin, s.v. “Sed-Fest” in L $\ddot{A}$ V 782-890; Hornung and Staehelin, 2006, pp. 41-46.

75. Winter, 1997; Hornung and Staehelin, 2006, pp. 32 and 89.

76. We should take into consideration the temple of Esna in which Hadrian is depicted in Pharaonic clothes in a way that let us figure out a connection with the Sed festival: Hornung and Staehelin, 2006, pp. 32 and 76. 


\section{Conclusions}

The analysis of the presence of the phoenix on the Hadrianic coins and the crater of the Capitoline Museums, together with the complex universe of signs that accompanies it, offers several possibilities to clarify, at least in part, the enigmatic religious and ideological system built into the Hadrianic environment. The comparative vision of these two cases clarifies the intercultural commitment, to which specialists of heterogeneous origin, and therefore also Egyptians, probably contributed. The Capitoline Museums' crater remains an object which is difficult to interpret. While providing data for an Egyptological analysis, it keeps to a narration that is not entirely clear. On the other hand, the use of Egyptian forms and signs must in itself express participation in an exclusive knowledge, ${ }^{77}$ rather than open a clear discourse. While retaining a cultured and not immediately accessible language, the coins are intended for wide dissemination; as per the crater, however, as well as other creations specifically linked to the Pharaonic world, a reserved language was chosen; a language that, as it happens in the Egyptian tradition and in Pharaonic magical thought, aims not so much to communicate something but to call it into existence, while simultaneously expressing participation in an elitist knowledge.

The Hadrianic coins, characterized by themes of Egyptian origin, are numerous and different, and they seem to be in parallel with themes that recur in other Egypt-expired creations, with particular attention to the regeneration of the sovereign and of the individual in a cosmic framework, as is the case in the Pharaonic tradition. In this context, the phoenix is an important theme, which we got to know earlier thanks to the coins, and then again towards the end of Hadrian's reign, at a time not so far from when the crater was created, after Hadrian's trip to Egypt. On the path traced by the coins and the crater we find some common characters: the regenerating transfer of royalty, that in one case - the coins - refers to the passage from Trajan to Hadrian, and in the other case - the figures on the crater - refers to the passage from Hadrian to Antinous, with a return to Hadrian himself. We also find in both cases the occurrence of cyclical time and astral references as well as the image of the phoenix. These themes are reflected in other monuments and expressions of the period of Hadrian, such as the attention to astronomy, a subject that has been well analyzed in a recent study of Hadrian's Villa: ${ }^{78}$ the interest in astral coincidences and significant dates is detected at Hadrian's Villa and returns in the coins of the Saeculum aureum with the phoenix. Another theme is the recovery of the ancient Pharaonic vision of the

77. Capriotti Vittozzi, 2013a, pp. 75-80, 151-160, with previous bibliography.

78. Frischer et al., 2016. 
passage between father and son, the coexistence between the Osiriac figure and the young solar deity, which finds an important expression in Hadrian's Gate at Philae. ${ }^{79}$ Such a theme is newly repurposed, thus following the path of tradition. The circularity of these figures, which is a tradition of the Pharaonic vision, is well visualized, in a new way, in the figurations of the Capitoline crater. In this passage, which refers to the image of the phoenix, and that is also found in the classical authors, the role of the journey must also be observed; this is brought to light in the account by Herodotus and, as E.M. Ciampini pointed out, it is found in the Pharaonic tradition: the "narrative circularity", that is typical of the phoenix's story - according to the A-B-A' scheme - is widely found in travel literature, such as in the famous Sinuhe tale. ${ }^{80}$ The theme of the return strongly impregnates Egyptian thought, in all its path, from the cosmogonic myths, to the stories of travel, from the myths connected with the return of the flooding of the Nile to the story of the solar Eye, that E. Bresciani ${ }^{81}$ calls "philosophical dialogue" between the monkey and the cat, having "the return" as its topic. Considering this legacy, which manifests itself from the aureus depicting Trajan and the phoenix together, we may take into account the importance of the theme of the journey during the reign of Hadrian, from that first journey bringing him back from the East to Rome, as a new phoenix, to the journey from Egypt, going again from East to West, after the loss of Antinous, a tragic event, though full of elaborations related to the theme of regeneration.

Finally, it seems interesting to widen the gaze on the thematic horizon of the cyclical renewal in a Pharaonic key, given another recurring image in the Hadrianic environment: the Apis bull. In fact, a periodic appearance is attributed to this, as well as to the phoenix. The cyclical nature of these figures is connected with those of the sun and the flood, but also to that of the Sothis star, whose heliacal rising would have been expected at the end of Hadrian's empire, ${ }^{82}$ and it also played a part in the socalled Antinoeion of Hadrian's Villa. ${ }^{83}$

The cult of the Apis is one of the oldest cults in Egypt. ${ }^{84}$ It has been attested since the beginning of Pharaonic history and it had a clear link with the rituals of royalty, and we know from classical sources up to the Roman period, how that link remained

79. Junker, 1913, pp. 37-45; Meyboom, 1995, pp. 132-135.

80. Ciampini, 1999, pp. 36-37.

81. Bresciani, 1992.

82. According to Censorinus, this happened in 139: O’ Mara, 2003; Quet, 2004.

83. Frischer et al., 2016.

84. Winter, 1978; Vercoutter, “Apis" in $L \ddot{A}$ I, 338-350. 
alive and important. Alexander would have venerated the sacred animal; ${ }^{85}$ Augustus had refused to pay him homage ${ }^{86}$ while Germanicus would have been disdained by it. ${ }^{87}$ We know from Suetonius that Titus, on his way back from Judea, had venerated the Apis and this had earned him suspicions about his claims with respect to the empire: ${ }^{88}$ the classical sources, therefore, clearly connect the Apis to the royal and imperial perspective.

Images of the Apis in the Hadrianic period are found on various coins ${ }^{89}$ but the most impressive appearance of the Apis is the dedication of a splendid statue in the Serapeum of Alexandria,${ }^{90}$ in addition to the fine bifronted image in the Vatican Museums from Hadrian's Villa. ${ }^{91}$

This important divine hypostasis, whose cult was connected with that of the god Ptah of Memphis, had contributed to the Hellenistic creation of the god Serapis, Osiris-Apis. ${ }^{92}$ We know from the Historia Augusta that the finding of a new Apis bull had generated disorders in the time of Hadrian. ${ }^{93}$

The Alexandrian statue, with its great proportions, ${ }^{94}$ carries the dedication of the emperor to Serapis and the sunnaoi gods. We do not know exactly when it was dedicated in the Serapeum of Alexandria.

The exquisite sculpture of the Apis in the Vatican Museums is one of a kind: a bifronted divinity that rises from the lotus flower. It is Osiris with a human face and with the taurine head of Apis, hence Osiris-Apis, on the lotus flower. This position, typical of the solar child, connects the Osiriac aspect and that of the solar rebirth in the same image. ${ }^{95}$

85. Arr., Anab. III 1; Alex. I 34.

86. Suet., Aug. 93; Cass. Dio, LI 16, 5.

87. Plin., HN VIII 71, 185.

88. Suet., Tit. V 4.

89. Kater Sibbes and Vermaseren, 1977, pp. 10-12, nn. 21-29.

90. Savvopoulos and Bianchi, 2012, pp. 56-60.

91. Inv. 22866. Botti and Romanelli, 1951, p. 129, n. 214, tav. LXXXVII; Vermaseren, M.J., s.v. "Apis", in LIMC II.1, 181, n. 334; II.2, 181.

92. Clerc and Leclant, s.v. "Osiris", in LIMC VII.1, 108 and "Sarapis", VII.1, 666. Among the wide existing literature see the recent study by Smith, 2017, pp. 390-400.

93. HA, Hadr. XII 1. On the possibility of a relation between these events and the other events mentioned by Dio Cassius (LXIX 8, 1a), which were quelled by a letter of the Emperor, see Capponi, 2010b; Horbury, 2014, p. 211. According to Birley, 2013, p. 142 this event could have happened between 121 and 122 .

94. H. $1.90 \mathrm{~m}$.

95. Grenier, 1990, pp. 16-17, with previous bibliography; Capriotti Vittozzi, 2009, pp. 66-67. 
From the same Greco-Roman sources, starting from Plutarch, ${ }^{96}$ probably due to a misunderstanding, we know how a precise lifespan was attributed to the sacred animal: twenty-five years, where twenty-five is also considered as a symbolic number. At the end of the "lifespan of the Apis", the animal would then die in the Nile. ${ }^{97} \mathrm{Al}$ though this conception did not find confirmation in the Pharaonic tradition, it is easy to imagine how suggestive it would be in relation to the death of the young Antinous, full of meanings regarding the regeneration of royalty. The attention in the Hadrianic period to the sacred bull of Memphis, a theme that had accompanied regeneration and regal rites from times immemorial, must therefore be included in the larger picture already described where animal figures with a strong symbolic meaning, such as the phoenix and the bull, also clarify how the myths and traditional rituals of the great areas of Memphis and Heliopolis were still able to find expression and provide elements for the discourse connected with the imperial ideology.

96. De Is. et Os. 56.

97. Vercoutter, s.v. "Apis" in $L A ̈ \mathrm{I}$, in particular pp. 346-348. 


\section{BIBLIOGRAPHY}

Adembri, B. (2012). Villa Adriana e l'Egitto. In Sapelli Ragni, 2012, pp. 91-107.

Asheri, D., Lloyd A. and Corcella, A. (2007). A Commentary on Herodotus, Libri 1-4. Oxford: Oxford University Press.

Barnes, T.D. (1976). The Horoscope of Licinius Sura?. Phoenix, 30.1, pp. 76-79.

Bell, L. (1985). Luxor Temple and the Cult of the Royal Ka. Journal of Near Eastern Studies, 44, pp. 251-294.

Birley, A.R. (2013). Hadrian: The Restless Emperor. London: Routledge ( ${ }^{\text {st }}$ edition 1997).

Bleeker, C.J. (1967). Egyptian Festivals: Enactments of Religious Renewal. Leiden: E.J. Brill.

Botti, G. and Romanelli, P. (1951). Le sculture del Museo Gregoriano Egizio. Città del Vaticano: Tip. poliglotta vaticana.

Bresciani, E. (1992). Il mito dell'Occhio del Sole: i dialoghi filosofici tra la Gatta Etiopica e il Piccolo Cinocefalo. Brescia: Paideia.

Bresciani, E. (1996). Il volto di Osiri: tele funerarie dipinte nell'Egitto romano. Lucca: Pacini Fazzi.

Buzi, P. (2013). Oracoli, visioni, profezie. L'Egitto da Alessandro il grande all'Alto Medioevo. Studi e Materiali di Storia delle Religioni LXXIX.1. Roma: Morcelliana.

Calandra, E. (2010). Villa Adriana scenario del potere. In Rizzi, 2010, pp. 21-50.

Camuzzi, G. (1901a). La consecratio di Traiano. Rivista Italiana di numismatica e scienze affini, 14 , pp. 11-26.

Camuzzi, G. (1901b). La consecratio nelle monete da Cesare ad Adriano. Rivista Italiana di numismatica e scienze affini, 14, pp. 27-53.

Capponi, L. (2010a). Hadrian in Jerusalem and Alexandria. Atheneum, 98, pp. 489-501.

Capponi, L. (2010b). Serapis, Boukoloi and Christians from Hadrian to Marcus Aurelius. In Rizzi, 2010, pp. 121-139.

Capponi, L. (2017). Il ritorno della fenice. Intellettuali e potere nell'Egitto romano. Studi e testi di storia antica XXIII. Pisa: ETS.

Capriotti Vittozzi, G. (2005). La montagna, la pietra, la porta, l'albero nell'immaginario egizio. In Atti della Giornata di studio "Porte basaltiche della Siria bizantina", Università "Roma Tre", 15 dicembre 2005, http://host.uniroma3.it/laboratori/arteconservazione1/ doc/Capriotti_Testo.pdf.

Capriotti Vittozzi, G. (2009). L'imperatore Adriano e la religione egizia alla luce delle recenti scoperte. In Gnoli and Sfameni Gasparro, 2009, pp. 49-74.

Capriotti Vittozzi, G. (2013a). La terra del Nilo sulle sponde del Tevere. Collana di Studi di Egittologia e Civiltà Copta I. Roma: Aracne.

Capriotti Vittozzi, G. (2013b). Lampade e visioni. Forme oracolari di origine egizia. In Buzi, 2013, pp. 47-59.

Capriotti Vittozzi, G. (2016). Antinous in the cosmic cycle. Interpretative elements in the light of Egyptian tradition. In Frischer et al., 2016, pp. 72-76. 
Christol, M. (1976). L’image du phénix sur les revers monétaires au milieu du IIIe siècle : une référence à la crise de l'Empire?. Revue Numismatique, 18, pp. 82-96.

Ciampini, E.M. (1999). La fenice, il serpente e il tempo. Studi e Materiali di Storia delle Religioni, 23, pp. 31-40.

Ciampini, E.M. (2005). The Pamphili Obelisk: Two Notes on Pharaonic Elements in Domitian Ideology. In Sanader and Miočevič, 2005, pp. 399-402.

Coulon, L. (2013a). Osiris chez Hérodote. In Coulon, Giovannelli-Jouanna and KimmelClauzet, 2013, pp. 167-190.

Coulon, L., Giovannelli-Jouanna, P. and Kimmel-Clauzet, F. (2013). Hérodote et l'Égypte. Regards croisés sur le Livre II de l'Enquête d'Hérodote. Actes de la journée d'étude organisée à la Maison de l'Orient et de la Méditerranée - Lyon, le 10 mai 2010. Collection de la Maison de l'Orient méditerranéen ancien. Série littéraire et philosophique LI). Lyon: Maison de l'Orient et la Méditerranée.

Davies, N. de Garis (1943). The Tomb of Rekh-mi-Rè at Thebes. Publications of Metropolitan Museum of Art Egyptian expedition XI. New York: Metropolitan Museum of Art.

Diegi, R. (2013). La raffigurazione della leggendaria fenice su alcune monete dell'antichità dall' impero di Roma al Regno delle Due Sicilie. Panorama Numismatico, 288, pp. 7-14.

Dieleman, J. and Wendrich, W. (2013). UCLA Encyclopedia of Egyptology. Los Angeles.

El-Banna, E. (1989). À propos des aspects héliopolitains d'Osiris. BIFAO, 89, pp. 101-126.

Ensoli Vittozzi, S. (1990). Musei Capitolini. La Collezione Egizia. Milano: Silvana.

Étienne-Fart, M. (1994). De rebus quae geruntur... dans deux inscriptions ramessides. BIFAO, 94, pp. 133-142.

Fabrizio-Costa, S. (2001). Phénix: mythe(s) et signe(s). Colloque de Caen, 2000. Berne: Peter Lang.

Faulkner, R.O., Ogden, G. and Von Dassow, E. (2008). The Egyptian Book of the Dead: The Book of Going Forth by Day - The Complete Papyrus of Ani Featuring Integrated Text and Full-Color Images. San Francisco: Chronicle Books (1st edition 1998).

Franci, M. (2010). Astronomia egizia. Firenze: Edarc.

Frischer, B., Zotti, G., Mari, Z. and Capriotti Vittozzi, G. (2016). Archaeoastronomical experiments supported by Virtual simulation environments: Celestial alignments in the Antinoeion at Hadrian's Villa (Tivoli, Italy). Digital Applications in Archaeology and Cultural Heritage, 3, pp. 55-79.

Giardini, M., Calderoni, G., Jolivet, V., Mari, Z., Sadori, L. Susanna, F. and Tresseras, J. (2006). Indagini archeobotaniche su alcuni materiali degli horti Luculliani (Roma) e di Villa Adriana (Tivoli). In Morel, Tresseras and Matamala, 2006, pp. 129-144.

Gnoli, G, and Sfameni Gasparro, G. (2009). Potere e religione nel mondo indo-mediterraneo tra Ellenismo e tarda antichità. Atti dell' Incontro di studio della Società Italiana di Storia delle Religioni, Roma - ISIAO 28-29 ottobre 2004. Roma: ISIAO.

Grenier, J.-C. (1987). Les inscriptions hiéroglyphiques de l'obélisque Pamphili. MEFRA, 99, pp. 937-961. 
Grenier, J.-C. (1990). La décoration statuaire du "Serapeum" du "Canope" de la Villa Adriana. Roma (= MEFRA, 101 (1989), pp. 925-1019).

Grenier, J.-C. (2008). L'Osiris Antinoos. Cahiers Égypte Nilotique et Méditerranéenne I. Montpellier: Université Paul Valéry.

Grimm, A., Kessler, D. and Meyer, H. (1994). Der Obelisk des Antinoos: Eine kommentierte Edition und eine Einführung „Antinous and the Greek Renascence“. München : W. Fink Verlag.

Gury, Fr. (1984). Aiôn juvénile et l'anneau zodiacal: l'apparition du motif. MEFRA, 96, pp. 7-28.

Harris, K.H. (1978). The "De ave phoenice" of Lactantius: A Commentary and Introduction. Thesis University of British Columbia. https://open.library.ubc.ca/cIRcle/collections/ ubctheses/831/items/1.0094332.

Hawass, Z. (2003). Egyptology at the Dawn of the Twenty-first Century. Proceedings of the Eighth International Congress of Egyptologists Cairo, 2000, II. Cairo: American University in Cario Press.

Horbury, W. (2014). Jewish War under Trajan and Hadrian. Cambridge: Cambridge University Press.

Hornung, E. and Staehelin, E. (2006). Neue Studien zum Sedfest. Aegyptiaca Helvetica XX. Basel: Schwabe.

Janák, J. (2010). Spotting the Akh. The Presence of the Northern Bald Ibis in Ancient Egypt and Its Early Decline. Journal of the American Research Center in Egypt, 46, pp. 17-31.

Janák, J. (2013a). Northern Bald Ibis (Akh-Bird). In Dieleman and Wendrich, 2013, http:// digital2.library.ucla.edu/viewItem.do?ark=21198/zz002dwqt8.

Janák, J. (2013b). Akh. In Dieleman and Wendrich, 2013, http://digital2.library.ucla.edu/ viewItem.do?ark=21198/zz002gclpn.

Junker, H. (1913). Das Götterdekret über das Abaton. Vienna: In Kommission bei A. Holder.

Kákosy, L. (1964). Osiris-Aion. Oriens Antiquus, 3, pp. 15-25.

Kákosy, L. (1982). Phönix. LÄ, 4, pp. 1030-1039.

Kater-Sibbes, G.J.F. and Vermaseren, M.J. (1977). Apis III. Inscriptions, Coins and Addenda. Études Préliminaires aux Religions Orientales dans l'Empire Romain XLVIII.3. Leiden: Brill.

LÄ: Helck, W., Otto, E., Westendorf, W. (1975-1992) Lexikon der Ägyptologie 7 Bde., Wiesbaden: O. Harrassowitz.

Lafli, E., Buora, M. and Mastrocinque, A. (2012). A New Osiriform Lamp from Antioch in the Hatay Archaeological Museum. Greek, Roman, and Byzantine Studies, 52, pp. 421-439.

Lecocq, Fr. (2001). L'empereur romain et le phénix. In Fabrizio-Costa, 2001, pp. 27-56.

Lecocq, Fr. (2008a). Les sources égyptiennes du mythe du phénix. In Lecocq, 2008b, pp. 211 266.

Lecocq, Fr. (2008b). L'Égypte à Rome. Actes du Colloque de Caen, 2003. Cahiers de la MRSHCaen XLI. Caen. 
Lecocq, Fr. (2009). L'iconographie du phénix à Rome. Schedae, 6.1, pp. 73-106 : http://cermn. unicaen.fr/puc/images/preprint0062009.pdf.

LIMC : Lexicon Iconographicum Mythologiae Classicae. Zürich, München, Düsseldorf : Artemis \& Winkler Verlag.

López Benitez, J. (2015). Adriano, dios presente entre los griegos. Rasgos de emoción en la epigrafía délfica de la época. ARYS, 13, pp. 151-169.

Martin, J.P. (1974). Hadrien et le phénix. Propagande numismatique. In Seston, 1974, pp. 327-337.

Mattingly, H. (1936). Coins Of The Roman Empire In The British Museum, III, Nerva To Hadrian. London: Trustees of the British Museum.

Meyboom, P.G.P. (1995). The Nile Mosaic of Palestrina: Early Evidence of Egyptian Religion in Italy. Religions in the Graeco-Roman World CXXI. Leiden: Brill.

Morel, J.P., Tresseras Juan, J. and Matamala, J.C. (2006). The Archaeology of Crop Fields and Gardens. Proceedings of the 1st Conference on Crop Fields and Gardens. Bari: Edipuglia.

Neugebauer, O. and Van Hoesen, H.B. (1959). Greek Horoscopes. Memoirs of the American philosophical society XLVIII. Philadelphia: American Philosphical Society.

Nigg, J. (2016). The Phoenix: An Unnatural Biography of a Mythical Beast. Chicago: The University of Chicago Press.

O’ Mara, P. (2003). Censorinus, the Sothic Cycle, and the Calendar Year One in Ancient Egypt: The Epistemological Problem. Journal of Near Eastern Studies, 62, pp. 17-26.

Perdrizet, P. (1934). La tunique liturgique historiée de Saqqara. Monuments et mémoires de la Fondation Eugène Piot Année, 34.1-2, pp. 97-128.

Quet, M.H. (2004). L'aureus au zodiaque d'Hadrien, première image de l'éternité cyclique dans l'idéologie et l'imaginaire temporel romains. Revue Numismatique, 160, pp. 119154.

Quirke, S. (2001). The Cult of Ra Sun-worship in Ancient Egypt. London: Thames \& Hudson. Rizzi, M. (2010). Hadrian and the Christians. Berlin and New York: De Gruyter.

Sanader, M. and Rendić Miočevič, A. (2005). Religija i mit kao poticaj provincijalnoi plastici. Akti VIII. Međunarodnog kolokvija o problemima rimskog provincijalnog umjetničkog stvaralaštva, Religion and Myth as an Impetus for the Roman Provincial Culture. The Proceedings of the 8th International Colloquium on Problems of Roman Provincial Art. Zagreb.

Sapelli Ragni, M. (2012). Antinoo. Il fascino della bellezza. Milano: Mondadori Electa.

Savvopoulos, K. and Bianchi, R.S. (2012). Alexandrian Sculpture in the Graeco-Roman Museum. Graeco-Roman Museum Series I. Alessandria: Bibliotheca Alexandrina.

Servajean, F. (2007). Djet et Neheh: une histoire du temps égyptien. Montpellier: Université Paul Valéry-Montpellier III..

Servajean, F. (2011). Le conte des Deux Frères (2). La route de Phénicie. ENIM, 4, pp. 197-232. Seston, W. (1974). Mélanges d'histoire ancienne offerts à William Seston. Paris: E. de Boccard. Smith, M. (2017). Following Osiris: Perspectives on the Osirian Afterlife from Four Millennia. Oxford: Oxford University Press. 
Staehelin, E. and Jaeger, B. (1997). Ägypten-Bilder. Akten des Symposions zur Ägypten-Rezeption, Augst bei Basel, vom 9.-11. September 1993. Freiburg and Göttingen: Vandenhoeck \& Ruprecht.

Stephens, S.A. (2003). Seeing Double: Intercultural Poetics in Ptolemaic Alexandria. Hellenistic Culture and Society XXXVII. Oakland: University of California Press.

Tammisto, A. (1986). TAMMISTO, PHOENIX · FELIX · ET · TV. Remarks on the representation of the Phoenix in Roman art. Arctos. Acta philological fennica, 20, pp. 170-225.

Teissier, B. (1996). Egyptian Iconography on Syro-Palestinian Cylinder Seals of the Middle Bronze Age. Göttingen: University Press Fribourg Switzerland Vandenhoeck \& Ruprecht Göttingen.

Tolmatcheva, E.G. (2003). A Reconsideration of the Benu-bird in Egyptian Cosmogony. In Hawass, 2003, pp. 522-526.

Uphill, E. (1965). The Egyptian Sed-Festival Rites. Journal of Near Eastern Studies, 24, pp. 365-383.

van den Broek, R. (1972). The Myth of the Phoenix: According to Classical and Early Christian Traditions. EPRO XXIV. Leiden: Brill.

Wallert, I. (1962). Die Palmen im a lten Ägypten: eine Untersuchung ihrer praktischen, symbolischen und religiösen Bedeutung. MÄS I. Berlin: Hessling.

Wb: Erman, A. and Grapow, H. (1926-1961). Wörterbuch der Ägyptischen Sprache, I-VI. Berlin.

Winter, E. (1978). Der Apiskult im Alten Ägypten. Mainz: Novo Industrie.

Winter, E. (1997). Ägyptologisches zum Antinoos. In Staehelin and Jaeger, 1997, pp. 97-102. 